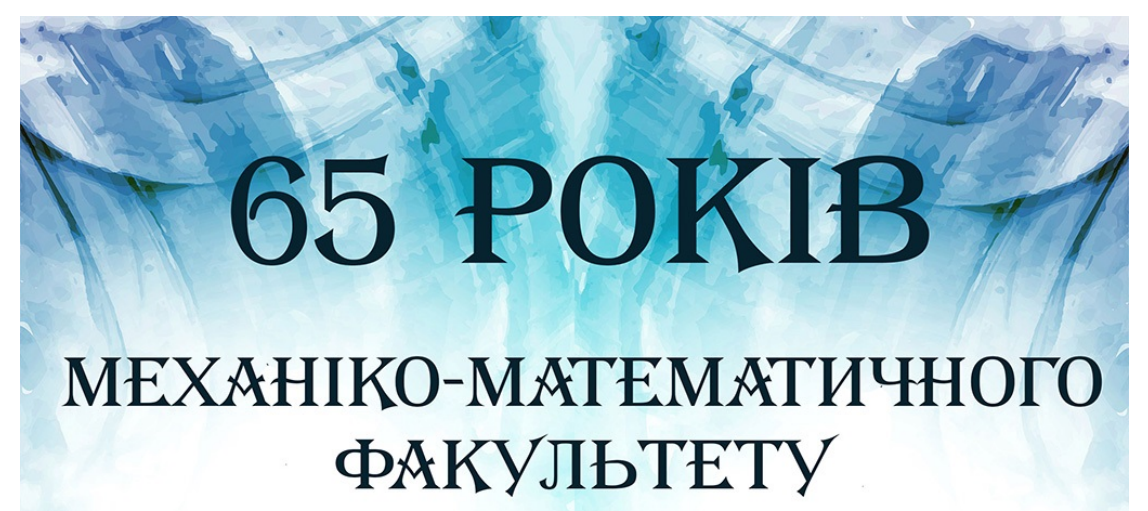

\title{
УРОЧИСТА АКАДЕМІЯ
}

\section{УРОЧИСТА АКАДЕМІЯ, ПРИСВЯЧЕНА 65-ТИ РІЧЧЮ МЕХАНІКО-МАТЕМАТИЧНОГО ФАКУЛЬТЕТУ}

3 грудня 2018 року о 15 годині в 216 аудиторії головного корпусу Львівського національного університету імені Івана Франка відбулася Урочиста Академія, присвячена 65-ти річчю механіко-математичного факультету Львівського університету.

1. Вступне слово.

\section{Програма}

Ігор Гуран, доцент, в. о. декана механіко-математичного факультету.

2. 'Історія викладання та наукових досліджень математики у Львівському університеті"

Ярослав Притула, доцент кафедри математичного та функціонального аналізу.

3. "Механіка у Львівському університеті"

Георгій $\boldsymbol{C у л и м , ~ з а в і д у в а ч ~ к а ф е д р и ~ м е х а н і к и . ~}$

4. "Про Математика 21-го століття"

Михайло Зарічний, професор кафедри геометрії і топології, 